\title{
ANALISIS SISTEM PEMBIAYAAN PADA PERBANKAN SYARIAH
}

\author{
Dr. Rahmat Ilyas, M.S.I \\ IAIN Syaikh Abdurrahman Siddik Bangka Belitung \\ mtd_82@yahoo.com
}

\begin{abstract}
Abstrak
Sistem keuangan dan perbankan Islam merupakan bagian dari konsep yang lebih luas tentang ekonomi Islam, dimana tujuannya adalah memberlakukan sistem nilai dan etika Islam ke dalam lingkungan ekonomi.Larangan riba dalam Islam, sebagaimana juga dalam beberapa agama lain, dan inspirasi umat Islam untuk menerapkan larangan ini dalam kehidupan ekonomi telah merangsang terbentuknya sejumlah lembaga keuangan syariah diseluruh penjuru dunia dalam tiga dekade terakhir.Diantara lembaga tersebut adalah bank komersial dan investasi, perusahaan asuransi (takaful), perusahaan leasing dan mudharabah serta lembaga non lainnya.Lembaga keuangan merupakan lembaga yang mempertemukan antara pihak yangmempunyaikelebihandana(surplus of funds)denganpihakyang mengalami kekurangan dana (lack of funds). pentingnya lembaga keuangan sebagai salah Satupilar ekonomi dapat dilihat dari berbagai kebijakan pengucuran dana pinjaman usaha berbagai usaha.
\end{abstract}

Kata kunci: Islam, Riba, Pembiayaan

\begin{abstract}
The Islamic finance and banking system is part of a broader concept of Islamic economics, whose goal is to introduce Islamic values and ethics into the economic environment. The prohibition of usury in Islam, as well as in some other religions, and the inspiration of Muslims to impose this ban on economic life have stimulated the formation of a number of Islamic financial institutions throughout the world in the last three decades. Among these institutions are commercial and investment banks, insurance companies (takaful), leasing companies and mudharabah and other non-institutions. Financial institutions are institutions that bring together those who have surplus of funds with a party lacking funds (lack of funds). the importance of financial institutions as one of the pillars of the economy can be seen from various policies disbursement of business loan funds various businesses.
\end{abstract}

Keywords: Islam, Riba, Financing

\section{PENDAHULUAN}

Kehidupan ekonomi pada mulanya masih bersifat simpel dan kegiatan produksi, konsumsi dan distribusi yang dilakukan masih sederhana. Seiring dengan perkembangan zaman populasi manusia mengalami pertumbuhan sehingga 
2 | Rahmat Ilyas

kegiatan ekonomi yang ada juga mengalami peningkatan. Kondisi membutuhkan fasilitas perdagangan untuk memenuhi kebutuhan sehari-hari. Fenomena tersebut mendorong masyarakat untuk mencari guna untuk mendirikan perusahaan, dan disisi lain terdapat sekelompok orang yang mempunyai kelebihan dana dan bermaksud untuk melakukan investasi. Dalam perjalanannya timbul keinginan untuk mendirikan lembaga intermeditasi untuk mempertemukan pihak yang kelebihan dana dengan pihak yang membutuhkan dana,yang mana lembaga tersebut dikenal dengan bank.

Sistem keuangan dan perbankan Islam merupakan bagian dari konsep yang lebih luas tentang ekonomi Islam, dimana tujuannya adalah memberlakukan sistem nilai dan etika Islam ke dalam lingkungan ekonomi. Karena dasar etika inilah, maka keuangan dan perbankan Islam bagi kebanyakan muslim adalah bukan sekedar sistem transaksi komersial. Persepsi Islam dalam transaksi finansial itu dipandang oleh kebanyakan muslim sebagai kewajiban agama. Kemampuan lembaga keuangan Islammenarik investor dengan sukses bukan hanya tergantung pada tingkat kemampuan lembaga itu menghasilkan keuntungan, tetapi juga pada persepsi bahwa lembaga tersebut sungguh-sungguh memperhatikan batas-batas yang digariskan oleh Islam. ${ }^{1}$ Larangan riba dalam Islam, sebagaimana juga dalam beberapa agama lain, dan inspirasi umat Islamuntuk menerapkan larangan ini dalam kehidupan ekonomi telah merangsang terbentuknya sejumlah lembaga keuangan syariah diseluruh penjuru dunia dalam tiga dekade terakhir.Diantara lembaga tersebut adalah bank komersial dan investasi, perusahaan asuransi (takaful), perusahaan leasing dan mudharabah serta lembaga non lainnya. ${ }^{2}$

\section{PEMBAHASAN}

\section{Perbankan Syariah}

Lembaga keuangan merupakan lembaga yang mempertemukan antara pihak yangmempunyaikelebihandana(surplusoffunds)denganpihakyang mengalami kekurangan dana (lack of funds). pentingnya lembaga keuangan sebagai salah Satupilar ekonomi dapat dilihat dari berbagai kebijakan pengucuran dana pinjaman

\footnotetext{
${ }^{1}$ Zainul Arifin, Dasar-dasar Manejemen Bank Syariah, (Jakarta:Pustaka Alvabet,2006), hlm .12

${ }^{2}$ M. Umer Chapra \& Tariqullah Khan, Regulasi \& Pengawasan Bank Syariah, (Jakarta: Bumi Aksara, 2008), hlm. 1
} 
usaha berbagai usaha. Lembaga keuangan dalam suatu perekonomianibarat seperti jantung dalam tubuh manusia, jika jantungmanusia sehat dapat berfungsi mengutur sirkulasi darah keseluruh tubuh makaKesehatan tubuh akan dapat terjaga. Namun jika jantung mengalami gangguan maka dapat mempengaruhi tingkat kesehatan tubuh.Demikian juga denganlembaga keuangan begitu penting dalam mempengaruhi sirkulasi uang dalam suatu perekonomian yang dapat berpengaruh terhadap kegiatan ekonomi secara keseluruhan.

Perkembangan perbankan syariah dimulai pada tahun 1975 dengan didirikannya Dubai lslamic Bank yang beroperasi sesuai dengan prinsip syariah. Langkah awal tersebut kemudian diikuti dengan berdirinya perbangkan dan lembaga investasi Islam lainnya yang mencapai 20 lembaga pada akhir tahun 1983, seperti lembaga perbankan Islam Bank Dubai Islam, Baitu al-Tanwil al.quwaity, Bank Faisal lslami dan Bank Bahrain Islami. ${ }^{3}$

Bank syariah dari satu negara kenegara lain, selain memiliki persamaan yang prinsip dan umum, juga memiliki perbedaan-perbedaan karena lingkungannya berbeda. Perbedaan ini juga tercermin pada variasi penggunaan akad yang berbeda dalam produk dan jasa yang ditawarkan bank syariah. Faktor-faktor yang mempengaruhi perbedaan tersebut bermacam-macam, antara lain;

1. Sistem ekonomi yang dianut oleh suatu negara

2. Aliran pemikiran/mazhab yang dianut negara/mayoritas penduduknya muslim.

3. Kedudukan bank syariah dalam undang-undang

4. Pendekatan pengembangan produk yang dipilih. 4

Suatu negara dapat menganut sistem ekonomi Islam secara penuh, sistem ekonomi ganda atau sistem ekonomi non Islam.Negara yang menganut sistem ekonomi Islampenuh memiliki infastruktur keuangan Islamyang lengkap dengan undang-undang yang berdasarkan syariah Islam.Sedangkan negara yang menganut sistem ekonomi ganda dapat memiliki infastruktur keuangan Islamyang bervariasi. Infastruktur keuangan Islamyang tidak lengkap akan menghambat dan membatasi ruang gerak perbankan syariah.

Berkaitan dengan hal itu Perbankan syariah di Indonesia sebagai salah satulembaga keuangan di Indonesia saat ini telah memasuki periode

\footnotetext{
${ }^{3}$ Said Sa'ad Marthon, Ekonomi Islam di Tengah Krisis Ekonomi Global, (Jakarta:Zikrul Hakim, tt), hlm. 125

4 Ascarya, Akad dan Produk Bank Syariah, (Jakarta:PT.RajaGrafindo Persada,2011), hlm. 131
} 
4 | Rahmat Ilyas

perkembanganyang sangat maju hal ini ditandai dengan berdirinya bank-bank syariah baru. Halini dimungkinkan dengan adanya landasan hukum yang jelas yaitu undang-undang No.10 tahun 1998 yang mengubah Undang-undang No.7 tahun1992 tentang perbankan serta peraturan-peraturan pelaksanaannya.Berdasarkan undangundang perbankan yang baru, sistem perbankan di Indonesia terdiri dari bank umum konvensional dan bank umum syariah. Selain itu undang-undang yang baru ini memungkinkan pengembangan syariah melalui pendirian banksyariah baru, perubahan kegiatan usaha bank konvensional menjadi bank syariahdan pelaksanaan kegiatan perbankan berdasarkan prinsip syariah oleh bankkonvensional.

Bank syariah di Indonesia, baik yang berbentuk bank umum syariah atau BUS, unit usaha syariah atau UUS, maupun bank perkreditan rakyat syariah atau BPRS berada dibawah undang-uandang perbankan No.10 Tahun 1998.Operasi perbankan dengan prinsip syariah sepenuhnya diakomodasi oleh undang-undang. Bank syariah di indonesia dapat melakukan transaksi berdasar titipan, pinjaman, bagi hasil, jual beli, sewa, dan prinsip lain yang dibolehkan syariah. Dengan demikian bank syariah di indonesia merupakan bank universal yang dapat berusaha sebagai consumer banking, invesment banking, merchant banking, leasing company, invesment agent, dan sebagai lembaga amil zakat dan sadaqah. ${ }^{5}$

\section{Pengertian Pembiayaan}

Dalam kegiatan penyaluran dana bank syariah melakukan investasi dan pembiayaan. Disebut investasi karena prinsip yang digunakan adalah prinsip penanaman dana atau penyertaan, dan keuntungan yang akan diperoleh bergantung pada kinerja usaha yang menjadi objek penyertaan tersebut sesuai dengan nisbah bagi hasil yang telah diperjanjikan sebelumnya. Disebut pembiayaan karena bank syariah menyediakan dana guna membiayai kebutuhan nasabah yang memerlukannya dan layak memperolehnya. ${ }^{6}$ Istilah pembiayaan pada intinya berarti I Believe, I Trust, saya percaya atau saya menaruh kepercayaan.Perkataan pembiayaan yang artinya kepercayaan berarti lembaga pembiayaan selaku shahibul mal menaruh kepercayaan kepada seseorang untuk melaksanakan amanah yang

\footnotetext{
${ }^{5}$ Ibid, hlm. 206

${ }^{6}$ Zainul Arifin, Dasar-dasar......, hlm. 200
} 
5 | Rahmat Ilyas

diberikan.Dana tersebut harus digunakan dengan benar, adil, dan harus disertai dengan ikatan dan syarat-syarat yang jelas, dan saling menguntungkan kedua pihak.

Dalam keseharian perbankan syariah mempunyai dua fungsi utama yaitu mengumpulkan dan menyalurkan dana. Penyaluran dana yang dilakukan bank syariah adalah pemberian pembiayaan kepada debitur yang membutuhkan, baikuntuk modal usaha maupun untuk konsumsi. Praktik pembiayaan yangsebenarnya dijalankan oleh lembaga keuangan Islami adalah pembiayaan dengan sistem bagi hasil atau syirkah.Praktik syirkah ini dikemas dalam dua jenispembiayaan,yaitu pembiayaan mudharabah (MDA) dan pembiayaan musyarakah (MSA). Adapun defenisi dari pembiayaan secara luas yaitu financing atau pembelanjaan, yaitu pendanaan yang dikeluarkan untuk mendukung investasi yang telah direncanakan, baik yang dilakukan sendiri maupun yang dijalankan oranglain. Dalam arti sempit pembiayaan dipakai untuk mendefenisikan pendanaanyang dilakukan oleh lembaga pembiayaan, seperti bank syariah kepada nasabah.7 Dalam melaksanakan pembiayaan tidak boleh keluar dari lima segi aturan-aturanatau norma-norma Islam yaitu:

1. Tidak ada transaksi keuangan berbasis bunga

2. Pengenalan pajak atau pemberian sedekah, zakat.

3. Pelarangan produksi barang dan jasa yang bertentangan dengan nilai Islam

4. Penghindaran aktivitas ekonomi yang melibatkan maysir atau judi dan gharar (ketidakpastian)

5. Penyediaan takaful (asuransi lslam) ${ }^{8}$

Tugas pokok lembaga pembiayaan adalah menghimpun dana dari masyarakat dan menyalurkan kepada masyarakat yang memerlukannya sehingga peranan pembiayaan menjadi sangat penting. Sebagian besar lembaga pembiayaan masih mengandalkan sumber pendapatan utamanya dari operasional pembiayaan sehingga untuk mendapatkan margin yang baik diperlukan pengelolaan pembiayaan secara efektif dan efisien.Lembaga keuangan adalah lembaga bisnis yang bergerak dalam pembiayaan dan jasa keuangan lainnya.

\section{Unsur Pembiayaan Bank Syariah}

\footnotetext{
${ }^{7}$ Muhammad, Manajemen Bank Syariah (Yogyakarta, AMP YKPN, 2005) hlm. 304

${ }^{8}$ Lativa M Algaoud \& Mervyn K Lewis, Perbankan Syariah Prinsip Praktik dan Prospek, (Jakarta:Serambi Ilmu Semesta, 2003), hlm. 48
} 
6 | Rahmat Ilyas

Pembiayaan pada dasarnya diberikan atas dasar kepercayaan.Dengan demikian, pemberian pembiayaan adalah pemberian kepercayaan.Hal ini berarti prestasi yang diberikan benar-benar harus diyakini dapat dikembalikan oleh penerima pembiayaan sesuai dengan waktu dan syarat-syarat yang telah disepakati bersama. Berdasarkan hal diatas, unsur-unsur pembiayaan antara lain;

1. Adanya dua pihak, yaitu pemberi pembiayaan atau shahibul mal dan penerima pembiayaan atau mudharib. Hubungan antara pemberi pembiayaan dan penerima pembiayaan merupakan kerjasama yang saling menguntungkan, yang diartikan pula sebagai kehidupan tolong menolong sebagaimana firman Allah dalam surah Al-Maidah ayat 2:

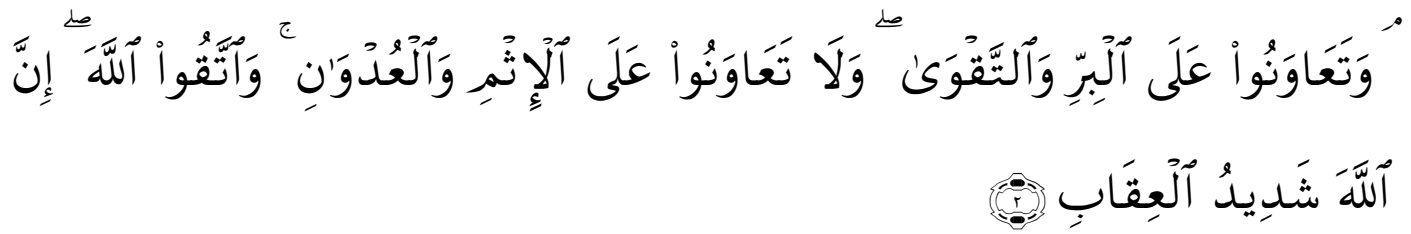

dan tolong-menolonglah kamu dalam (mengerjakan) kebajikan dan takwa, dan jangan tolong-menolong dalam berbuat dosa dan pelanggaran. dan bertakwalah kamu kepada Allah, Sesungguhnya Allah Amat berat siksa-Nya.

2. Adanya kepercayaan shahibul mal kepada mudharib yang didasarkan atas prestasi dan potensi mudharib.

3. Adanya persetujuan, berupa kesepakatan pihak shahibul mal dengan pihak lainnya yang berjanji membayar dari mudharib kepada shahibul mal. Janji membayar tersebut dapat berupa lisan, tertulis (akad pembiayaan) atau berupa instrument (credit Instrument). Hal ini sebagaimana firman Allah dalam surah Al-Baqarah ayat 282.

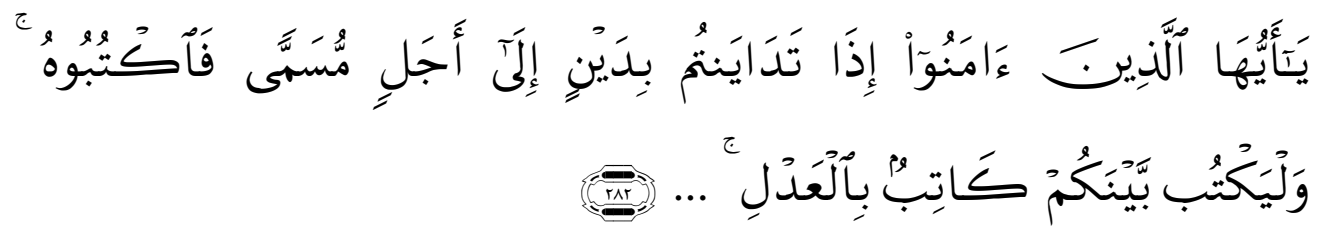

Hai orang-orang yang beriman, apabila kamu bermu'amalah tidak secara tunai untuk waktu yang ditentukan, hendaklah kamu menuliskannya. dan hendaklah seorang penulis di antara kamu menuliskannya dengan benar.

4. Adanya penyerahan barang, jasa atau uang dari shahibul mal kepada mudharib.

5. Adanya unsur waktu (time element). Unsur waktu merupakan unsur esensial pembiayaan. Pembiayaan terjadi karena unsur waktu, baik dilihat dari shahibul mal maupun dari mudharib. 
7 | Rahmat Ilyas

6. Adanya unsur resiko (degree of risk) baik di pihak shahibul mal maupun pihak mudharib. Risiko dipihak shahibul mal adalah risiko gagalbayar (risk of default), baik karena kegagalan usaha atau ketidakmampuan bayar atau karena ketidak sediaan membayar. Risiko dipihak mudharib adalah kecurangan dari pihak pembiayaan, antara lain berupa shahibul mal yang dari bermaksud untuk mencaplok perusahaan yang diberi pembiayaan atau tanah yang dijaminkan. ${ }^{9}$

\section{Tujuan Pembiayaan}

Secara umum tujuan pembiayaan dapat dibedakan menjadi kelompok yaitu: tujuan pembiayaan untuk tingkat mikro dan tujuan pembiayaan untuk tingkat makro. Secara makro pembiayaan bertujuan:

1. Peningkatan ekonomi umat, msyarakat yang tidak dapat akses secara ekonomi, dengan adanya pembiayaan mereka dapat melakukan akses ekonomi. Dengan demikian dapat meningkatkan taraf ekonomi.

2. Tersedianya dana bagi peningkatan usaha, untuk pengembangan usaha membutuhkan dana tambahan. Dana tambahan ini dapat diperoleh melakukan aktivitas pembiayaan.

3. Meningkatkan produktivitas, adanya pembiayaan memberikan peluang bagi masyarakat usaha mampu meningkatkan daya produksinya.

4. Membuka lapangan kerka baru, dengan dibukanya sektor-sektor usaha melalui penambahan dana pembiayaan, maka sektor usaha akan menyerap tenaga kerja.

5. Terjadinya distribusi pendapatan, masyarakat usaha produktif mampu melakukan aktivitas kerja.

Sedangkan mikro tujuan pembiayaan dalam rangka;

1. Upaya memaksimalkan harta, setiap usaha yang dibuka memiliki tujuan tertinggi yaitu menghasilkan laba usaha. Setiap pengusaha menginginkan mampu laba maksimal. Untuk dapat menghasilkan laba maksimal maka perlu dukungan dana yang cukup.

2. Upaya meminimalkan risiko, usaha yang dilakukan agar mampu menghasilkan laba yang maksimal, maka pengusaha harus mampu meminimalkan risiko yang timbul. Risiko kekurangan modal usaha dapat diperoleh melalui pembiayaan.

${ }^{9}$ Veithzal Rivai \& H. Arviyan Arifin, Islamic Banking, (Jakarta: Bumi Aksara, 2010), hlm. 710 
8 | Rahmat Ilyas

3. Pendayagunaan sumber ekonomi, sumber daya ekonomi dapat dikembangkan dengan melakukan mixing antara sumber daya alam dengan sumber daya manusia serta sumber daya modal. Jika sumber daya alam dan sumber daya manusia ada, dan sumber daya modal tidak ada. Maka dapat dipastikan diperlukan pembiayaan. Dengan demikian pembiayaan pada dasarnya dapat meningkatkan daya guna sumber-sumber daya ekonomi.

4. Penyaluran kelebihan dana, dalam kehidupan masyarakat ada pihak yang memiliki kelebihan sementara ada pihak yang kekurangan. Dalam kaitannya dengan masalah dana, maka mekanisme pembiayaan dapat menjadi jembatan dalam penyeimbangan dan penyaluran kelebihan dana dari pihak yang kelebihan kepada pihak yang kekurangan. ${ }^{10}$

\section{Jenis-jenis Pembiayaan}

Bank sebagai lembaga perantara jasa keuangan (financial intermediary) yang tugas pokoknya adalah menghimpun dana dari masyarakat, diharapkan dengan dana dimaksud dapat memenuhi kebutuhan dana pembiayaan yang tidak disediakan oleh dua lembaga sebelumnya baik lembaga negara mapun swasta. Adapun salah satu produk dari bank syariah adalah Pembiayaan atau financing, yaitu pembiayaan yang diberikan oleh suatu pihak kepada pihak lain untuk mendukung investasi yang telah direncanakan, baik dilakukan sendiri maupun lembaga. Dengan kata lain, pembiayaan adalah pendaan yang dikeluarkan untuk mendukung investasi yang telah direncanakan. ${ }^{11}$

Pembiayaan merupakan salah satu tugas pokok bank, yaitu pemberian fasilitas penyediaan dana untuk memenuhi kebutuhan pihak-pihak yang merupakan defisit unit. Menurut sifat penggunaannya, pembiayaan dapat dibagi menjadi dua: pertama, Pembiayaan produktif, yaitu pembiayaan yang ditujukan untuk memenuhi kebutuhan produksi dalam arti luas, yaitu untuk peningkatan usaha, baik usaha produksi, perdagangan maupun investasi. kedua, Pembiayaan konsumtif, yaitu pembiayaan yang digunakan untuk memenuhi kebutuhan konsumsi, yang akan habis digunakan untuk dipakai memenuhi kebutuhan. ${ }^{2}$ Pembiayaan konsumtif diperlukan oleh pengguna dana untuk memenuhikebutuhan konsumsi dan akan

${ }^{10}$ Muhammad, Manajemen Pembiayaan Bank Syariah, (Yogyakarta:UMP YKPN, 2005), hlm. 18

${ }^{11}$ Ibid, hlm.17

12 Muhammad Syafii Antonio, Bank Syariah bagi Bankir \& Praktisi Keuangan, (Jakarta, TP, 1999), hlm. 219 
9 | Rahmat Ilyas

habis dipakai untuk memenuhi kebutuhan tersebut. Kebutuhan konsumsi dapat dibedakan atas kebutuhan primer (Pokok) dan kebutuhan sekunder. Pembiayaan komsumsi pada bank syariah lazim digunakan untuk memenuhi kebutuhan sekunder. Adapun kebutuhan primer pada umumnya tidak dapat dipenuhi dengan pembiayaan komersil. Seseorang yang belum mampu memenuhi kebutuhan pokoknya tergolong fakir atau miskin. Oleh karena itu ia wajib diberi zakat atau sedekah. Menurut keperluannya, pembiayaan produktif dibagi menjadi:

a. Pembiayaan Modal Kerja, yaitu pembiayaan untuk memenuhi kebutuhan (1) peningkatan produksi, baik secara kuantitatif, yaitu jumlah hasil produksi, maupun secara kualitatif yaitu peningkatan kualitas atau mutu hasil produksi. (2) untuk keperluan perdagangan atau peningkatan utility of palace dari suatu barang.

b. Pembiayaan Investasi, yaitu untuk memenuhi kebutuhan barang-barang modal (capital goods) serta fasilitas-fasilitas yang erat kaitannya dengan itu.

Secara umum jenis pembiayaan dapat digambarkan sebagai berikut:13

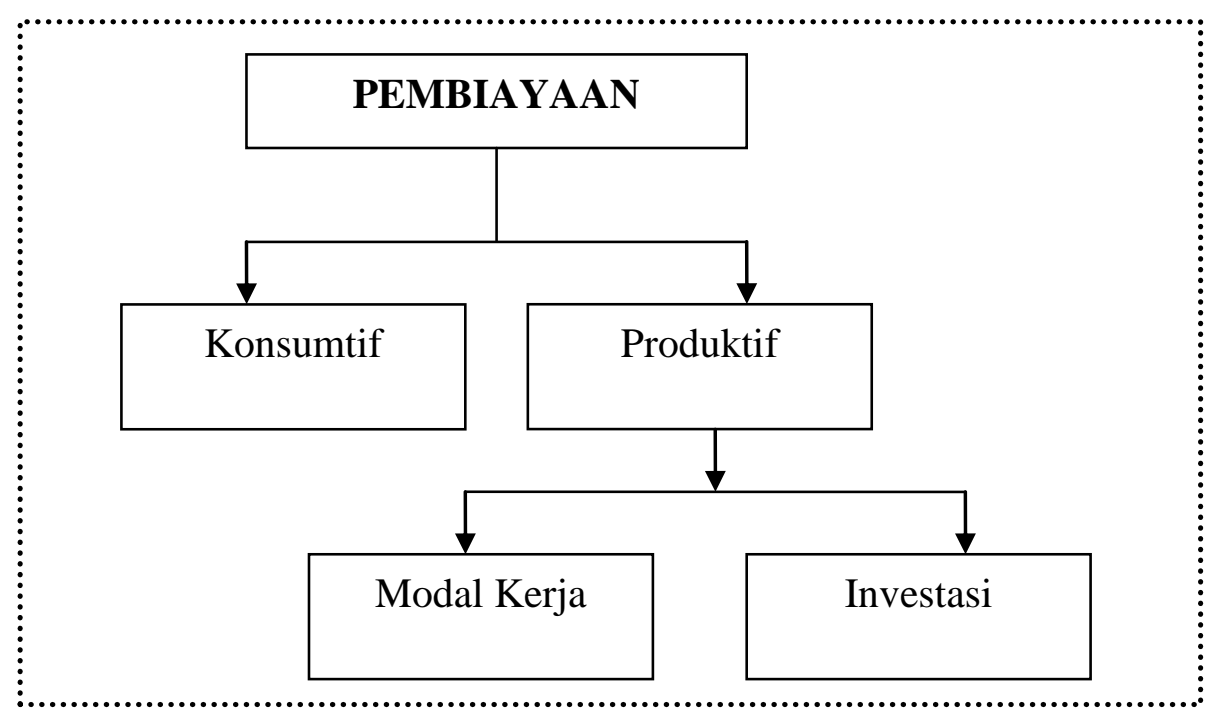

Dalam praktek bank syariah terdapat dua jenis pembiayaan, yaitu pembiayaan mudharabah dan pembiayaan musyarakah.Sedangkan Jenis pembiayaan lainnya adalah terkemas dalam pembiayaan berakad/sistem jual beli, yaitu pembiayaan murabahah, bai as-salam dan bai istishna. ${ }^{14}$ Pembiayaan Mudharabah adalah perjanjian antara penanam dana dan pengelola dana untuk melakukan kegiatan usaha tertentu, dengan pembagian keuntungan antara kedua belah pihak berdasarkan nisbah yang

\footnotetext{
${ }^{13}$ Muhammad Syafii Antonio, Bank Syariah dari Teori ke Praktik, (Jakarta, Gema Insani \& Tazkia Cendekia, 2007), hlm. 161

${ }^{14}$ Muhammad, Manajemen Bank Syariah....hlm.303
} 
10 | Rahmat Ilyas

telah disepakati sebelumnya. ${ }^{15}$ Dalam konteks mudharabah dilihat sebagai salah satu bentuk pembiayaan untuk mengangkat sistem bebas bunga, dimana bank akan mengeluarkan uang kepada perusahaan yang bergerak dalam sebuah kegiatan produktif atas prinsip keuntungan dan kerugian ditanggung bersama (Profit and loss sharing). Pembagian terhadap rasio keuntungan bagi bank harus ditentukan melalui perundingan antara kedua belah pihak. Akan tetapi kerugian, jika terjadi harus dibagi kedua belah pihakdengan proporsi yangsama, sebagai kontribusi pemilik modal yang disertakan dalam kegiatan bisnis bersama. ${ }^{16}$

Pembiayaan mudharabah terbagi kepada dua macam;

1. Mudharabah Muthlaqah, yaitu dimana mudharib diberikan hak yang tidak terbatas untuk melakukan investasi oleh shahibul mal.

2. Mudharabah Muqayyadah, yaitu dimana mudharib dibatasi haknya oleh shahibul mal, antara lain dalam jenis usaha, waktu, tempat usaha dan lain-lain.

Dalam dunia perbankan mudharabah biasanya diaplikasikan pada produk pembiayaan atau pendanaan seperti, pembiayaan modal kerja.Dana untuk kegiatan mudharabah diambil dari simpanan tabungan berjangka seperti tabungan haji atau tabungan kurban.Dana juga dapat dilakukan dari deposito biasa dan deposito spesial yang ditipkan nasabah untuk usaha tertentu. Pembiayaan Musyarakah adalah perjanjian diantara pemilik dana/modal untuk mencampurkan dana/modal mereka pada suatu usaha tertentu, dengan pembagian keuntungan diantara pemilik dana/modal berdasarkan nisbah bagi hasil yang telah disepakati sebelumnya.

Pembiayaan jenis musyarakah ini terbagi kepada lima macam:

1. Syirkah muwafadah, yaitu kerjasama atau percampuran dana antara dua pihak atau lebih dengan porsi dana yang sama

2. Syirkah al-Inan, yaitu kerjasama atau percampuran dana antara dua pihak atau lebih dengan porsi dana yang tidak mesti sama

3. Syirkah wujuh, yaitu kerjasama atau percampuran antara pihak pemilik dana dengan pihak yang lain yang memiliki kredibilitas ataupun kepercayaan.

4. Syirkah 'abdan, yaitu kerjasama atau percampuran tenaga atau profesionalisme antara dua pihak atau lebih (kerjasama profesi).

15 Muhammad, Manajemen Dana Bank Syariah, (Yogyakarta, Ekonisia, 2005), hlm.201

${ }^{16}$ Zubair Hasan, Bangunan Ekonomi yang berkeadilan, teori, Praktek dan realitas Ekonomi Islam, (Yogyakarta, Magistra Insani Perss \& MSI-UII, 2004), hlm. 188 
11 | Rahmat Ilyas

5. Syirkah al-mudharabah, yaitu kerjasama atau percampuran dana antara pihak pemilik dana dengan pihak lain yang memiliki profesionalisme atau tenaga. ${ }^{17}$

Dalam praktik perbankan musyarakah diaplikasikan dalam hal pembiayaan proyek. Nasabah yang dibiayai dengan bank sama-sama menyediakan dana untuk melaksanakan proyek tersebut. Keuntungan dari proyek tersebut dibagi sesuai dengan kesepakatan untuk bank setekah terlebih dulu mengembalikan dana yang dipakai nasabah. Musyarakah juga dapat dilakukan untuk kegiatan investasi seperti pada lembaga keuangan modal ventura.

\section{Analisis Pembiayaan}

Resiko pembiayaan bermasalah dapat diperkecil dengan melakukan berbagai cara yang salah satunya dengan metode analisa pembiayaan. Yang tujuan utamanya adalah menilai seberapa besar kemampuan dan kesediaan debitur dalam mengembalikan pembiayaan yang mereka pinjam dan membayar margin keuntungan dan bagi hasil sesuai dengan ini perjanjian pembiayaan. Analisis pembiayaan merupakan langkah penting untuk realisasi pembiayaan di bank syariah.Dalam analisis pembiayaan terdapat 5 prinsip dasar yang harus dijadikan pedoman. Adapun analisis tersebut dirumuskan dalam 5C yaitu:

a. Character adalah keadaan watak/sifat dari customer, baik dalam kehidupan pribadi maupun dalam lingkungan usaha. Kegunaan dari penilaian terhadap karakter ini adalah untuk mengetahui sampai sejauh mana iktikad/kemauan customer untuk memenuhi kewajiban sesuai dengan perjanjian yang ditetapkan.

b. Capital adalah jumlah dana atau modal sendiri yang dimiliki oleh calon mudharib. Makin besar modal sendiri dalam perusahaan, tentu semakin tinggi kesungguhan calon mudharib menjalankan usahanya dan bank akan merasa lebih yakin memberikan pembiayaan.

c. Capacity adalah kemampuan yang dimiliki calon mudharib dalam menjalankan usahanya guna memperoleh laba yang diharapkan. Kegunaan dari penilaian ini adalah untuk mengetahui/mengukur sampai sejauh mana calon mudharib mampu mengembalikan atau melunasi hutang-hutang secara tepat waktu.

d. Collaterial adalah barang yang diserahkan mudharib sebagai agunan terhadap pembiayaan yang diterimanya. Collaterial harus dinilai oleh bank untuk

${ }^{17}$ Suhartono Zulkifli, Panduan Praktis Transaksi Perbankan syariah, (Jakarta: Zikrul hakim, 2003), hlm.52 
mengetahui sejauh mana risiko kewajiban finansial mudharib kepada bank. Penilaian terhadap agunan meliputi jenis, lokasi, bukti pemilikan dan statusnya.

e. Condition of Economy adalah situasi dan kondisi politik, sosial, ekonomi dan budaya yang mempengaruhi keadaan perekonomian yang memungkinkan pada suatu saat mempengaruhi kelancaran perusahaan calon mudharib.

f. Constraints adalah batasan dan hambatan yang tidak memungkinkan suatu bisnis dilaksanakan pada tempat tertentu, misalnya pendirian suatu usaha pompa bensin yang disekitarnya banyak bengkel las/pembakaran batu bata. ${ }^{18}$

Disamping 6 prinsip dasar diatas perlu memperhatikan kondisi sifat amanah, kejujuran, kepercayaan dari masing-masing nasabah yang meminjam. Selain 6 prinsip diatas terdapat bebera pendekatan analisis pembiayaan yang dapat diterapkan oleh para pengelola bank syariah dalam mengantisipasi pembiayaan bermasalah yaitu:

a. Pendekatan jaminan, artinya bank dalam memberikan pembiayaan selalu memperhatikan kuantitas dan kualitas jaminan yang dimiliki oleh peminjam.

b. Pendekatan karakter, artinya bank mencermati secara sungguh-sungguh terkait dengan karakter nasabah

c. Pendekatan kemampuan pelunasan, artinya bank menganalisis kemampuan nasabah untuk melunasi jumlah pembiayaan yang telah diambil.

d. Pendekatan dengan studi kelayakan, artinya bank memperhatikan kelayakan usaha yang dijalankan oleh nasabah peminjam

e. Pendekatan fungsi-fungsi bank, artinya bank memperhatikan fungsinya sebagai lembaga intermediary keuangan, yaitu mengatur mekanisme dana yang dikumpulkan dengan dana yang disalurkan.19

Selain analisis pembiayaan dalam mengantisipasi terhadap terjadinya pembiayaan bermasalah perlu juga di perhatikan pada aspek penanganan resiko sehingga hal ini menjadi salah satu alat pencegahan terhadap terjadi pembiayaan bermasalah. Selain itu untuk mengurangi kemungkinan terjadinya resiko dalam pembiayaan, maka bank syariah seharusnya menerapkan sejumlah batasan-batasan tertentu ketika menyalurkan pembiayaan kepada mudharib. Adapun batasanbatasan yang dilakukan yaitu:

\footnotetext{
${ }^{18}$ Veithzal Rivai \& Andria Permata Veithzal, Islamic Financial Management (Jakarta: Rajawali Press, 2008), hlm. 348-352

${ }^{19}$ Muhammad, Manajemen Pembiayaan.....hlm. 60
} 
13 | Rahmat Ilyas

a. Menerapkan agar porsi modal dari pihak mudharibnya lebih besar atau mengenakan jaminan. Dalam ketentuan fiqih, kontrak mudharabah tidak boleh menggunakan jaminan. Jaminan boleh diminta oleh shohibul mal jika proyek yang dikembangkan menunjukkan tanda tidak baik. Jika demikian syarat yang ditetapkan untuk batasan ini meliputi:

1) Penetapan nilai maksimal rasio hutang terhadap modal. Bila porsi modal mudharib dalam suatu usaha relatif tinggi, maka insentifnya untuk berlaku tidak jujur akan berkurang dengan signifikan, karena itu juga akan menanggung kerugian atas tindakan tersebut.

2) Penetapan agunan berupa fixed asets. Pengenaan jaminan juga akan mencegah mudharib melakukan penyelewengan karena jaminan yang sudah diberikannya itu menjadi harga dari penyelewengan perilakunya.

3) Penggunaan pihak penjamin. Seringkali bank sebagai pemilik dana tidak mengenal karakter calon mudharib. Menghadapi situasi ini, bank dapat saja meminta agar calon mudhorib menyerahkan pihak calon penjamin yang mengenal dekat karakter calon mudharib

4) Penggunaan pihak pengambil alih hutang. Dalam beberapa kasus, pihak penjamin bersedia mengambil alih kewajiban calon mudharib bila terjadi kerugian yang disebabkan characterrisk calon mudharib.

b. Menerapkan syarat agar mudharib melakukan bisnis yang resiko operasinya lebih rendah.

c. Menetapkan syarat agar mudharib melakukan bisnis dengan arus kas trasparan.

d. menetapkan syarat agar mudharib melakukan bisnis yang biaya tidak terkontrolnya rendah. ${ }^{20}$

\section{Penggolongan Kolektabilitas Pembiayaan}

Ketidaklancaran nasabah membayar angsuran pokok pembiayaan menyebabkan adanya kolektabilitas pembiayaan. Secara umum kolektabilitas pembiayaan dikategorikan menjadi lima macam:

1. Lancar

Pembiayaan digolongkan lancar apabila memenuhi kriteria dibawah ini:

a. Tidak terdapat tunggakan angsuran pokok

${ }^{20}$ Muhammad, Konstruksi Mudharabah dalam Bisnis Syariah; Mudharabah dalam wacana Fiqih dan Praktek ekonomi Modern, (Yogyakarta, Pusat Studi Ekonomi Islam STIS, 2003), hlm.123-126 
b. Terdapat angsuran Pokok, tetapi:

a) belum melebihi I bulan, bagi pembiayaan yang ditetapkan masa angsurannya kurang dari I bulan

b) belum melebihi 3 bulan, bagi pembiayaan yang ditetapkan masa angsurannya bulanan, dua bulanan atau tiga bulanan.

c) Belum melampaui 6 bulan bagi pembiayaan yang masa angsurannya ditetapkan 4 bulanan atau lebih.

2. Kurang Lancar

Pembiayaan digolongkan kurang lancar apabila memenuhi kriteriadibawah ini:

a. Melampaui I bulan dan belum mencapai 2 bulan bagi pembiayaan dengan angsuran kurang dari I bulan,

b. Melampaui 3 bulan dan belum mencapai 6 bulan bagi yang angsurannya ditetapkan bulanan, dua bulanan atau tiga bulanan.

c. Melampaui 6 bulan tetapi belum melampaui 12 bulanan bagi pembiayaan yang masa angsurannya ditetapkan 6 bulanan atau lebih.

3. Diragukan

Pembiayaan digolongkan diragukan apabila pembiayaan yangbersangkutan tidak memenuhi kriteria lancar dan kurang lancar, sepertitersebut dalam kriteria lancar dan kurang lancar tetapi berdasarkan penilaiandapat disimpulkan bahwa:

a. Pembiayaan masih dapat diselamatkan dan agunannya bernilai sekurangkurangnya $75 \%$ dari hutang peminjam.

b. Pembiayaantidakdapatdiselamatkantetapiagunannyamasihbemilai sekurangkurangnya $100 \%$ dari hutang peminjam.

4. Macet

Pembiayaan yang digolongkan macet apabila:

a. Tidak memenuhi criteria lancar, kurang lancar dan diragukan

b. Memenuhi criteria diragukan tersebut tapi jangka waktu 21 bulan sejak digolongkan diragukan belum ada pelunasan atau penyelamatan

\section{Penanganan Pembiayaaan yang bermasalah}

Ada berbagai permasalahan yang potensial yang timbul dalam praktik perbankan syariah antara bank dengan nasabah.kemungkinan-kemungkinan sengketa biasanya berupa komplain karena ketidaksesuaian antara realitas dengan 
penawarannya, tidak sesuai dengan spesifikasinya, tidak sesuai dengan aturan main yang diperjanjikan, layanan dan alur birokrasi yang tidak masuk dalam draf akad, serta komplain terhadap proses layanan kerja.

Penyelesaian Pembiayaan bermasalah yang terjadi Lembaga bank syariah dilakukan dengan beberapa cara, yaitu:

1. Melalui Jalur Musyawarah Mufakat

Islam sebagai sebuah agama yang lebih mencintai perdamaian dan menjadi pedoman bagi pemeluk-pemeluknya.dalam hal sengketa muamalah yang timbul akan lebih utama jika diselesaikan melalui cara-cara damai (tasaluh). untuk itu para pihak yang ada sebaiknya lebih mengedepankan menempuh upaya musyawarah untuk mufakat ketika menghadapi sengketa. melalui upaya dialogis ini diharapkan hubungan bisnis dan persaudaraan yang ada dapat tetap terjalin dan lebih dapat menjaga hubungan diantara para pihak, serta dapat lebih hemat dari segi waktu dan biaya.

Upaya-upaya yang dilakukan sebagai langkah penyelamatan terhadap pembiayaan yang bermasalah dengan cara musyawarah yaitu dengan Proses revitalisasi atau penyehatan pembiyaan. Proses revitalisasi atau penyehatan pembiayaan dilakukan melalui:

1) rescheduling (Penjadwalan kembali)

Suatu tindakan yang diambil dengan cara memperpanjang jangka waktu kredit/jangka waktu angsuran. Dalam hal ini sidebitur diberikan keringanan dalam masalah jangka waktu kredit pembayaran kredit. misalnya perpanjangan jangka waktu kredit dari 6 bulan menjadi satu tahun hingga si debitur punya waktu yang lama untuk mengembalikannya.

2) Penataan Kembali (restructuring), yaitu perubahan ketentuan pembiayaan termasuk perubahan maksimum saldo pembiayaan

3) Perubahan persyaratan (reconditioning), yaitu menyangkut ketentuan pembiayaan dan persyaratan lain.

4) Bantuan manajemen yaitu dengan menempatkan sumber daya insani pada posisi manajemen oleh bank.

2. Penyelesaian Melalui Jaminan

Tindakan ini dilakukan pihak bank apabila upaya revitalisasi tidak dapat dilakukan karena nasabah sudah tidak lagi memiliki usaha dan sudah tidak 
16 | Rahmat Ilyas

kooperatif lagi dengan bank.upaya penyelesaian melalui jaminan ini dilakukan dengan penyerahan jaminan secara sukarela untuk dijual, melalui eksekusi rill jaminan serta memintakan bantuan badan arbitrase yang akan diteruskan kepengadilan negeri untuk mendapatkan pengesahan sehingga mempunyai kekuatan eksekutorial.

3. Melalui Proses Ligitasi

Tindakan ini dilakukan sebagai upaya terakhir yang dilakukan oleh pihak bank untuk pengembalian kembali sejumlah modalnya yang dapat dilakukan dengan maengajukan tuntutan pidana, gugatan perdata serta permohonan kepailitan.21

Kondisi iktikad dan kemampuan debitur, prospek usaha dan agunan adalah faktor-faktor yang paling menentukan jenis pengendalian yang akan dilaksanakan oleh bank. Pada saat kredit menjadi bermasalah kondisinya mungkin positif, mungkin negatif

Adapun kriteria untuk menentukan kondisi faktor-faktor tersebut adalah sebagai berikut:

a. Iktikad

1) Keterbukaan

2) Reaksi terhadap saran Bank

3) Keteraturan menyampaikan laporan

4) Kesediannya untuk dikunjungi

5) Kredit bank lain tanpa persetujuan bank

6) Transaksi keuangan melalui bank

7) Keteraturan membayar premi asuransi

8) Kesesuaian penggunaan kredit dengan rencana

9) Adanya overprice/mark up

10) Pandangan terhadap sebab terjadinya masalah

b. Kemampuan/Prospek

1) Kelengkapan dan perawatan mesin-mesin dan alat-alat produksi lainya.

2) Kondisi operasional lainnya

3) Peluang pasar, strategi pemasaran

4) Kemampuan menghasilkan laba

c. Jaminan

${ }^{21}$ Abdul Ghofur Anshori, Perbankan Syariah di Indonesia, (Yogyakarta, UGM Press, 2007), hlm. 185

Jurnal Hukum dan Ekonomi Syari'ah, Vol. 06 | Nomor 4 
17 | Rahmat Ilyas
1) Kemudahan untuk dijual
2) Adanya standar harga
3) Kestabilan harga
4) Kemudahan dipindahtangankan
5) Kondisi pengikatan
6) Kelengkapan dokumen pemilikan
7) Penguasaan dokumen pemilikan
8) Umur teknis/ekonomis
9) Nilai transaksi22

\section{KESIMPULAN}

Lembaga keuangan merupakan lembaga yang mempertemukan antara pihak yang mempunyai kelebihan dana (surplus of funds) dengan pihak yang mengalami kekurangan dana (lack of funds). pentingnya lembaga keuangan sebagai salah Satu pilar ekonomi dapat dilihat dari berbagai kebijakan pengucuran dana pinjaman usaha berbagai usaha. Istilah pembiayaan pada intinya berarti I Believe, I Trust, saya percaya atau saya menaruh kepercayaan.Perkataan pembiayaan yang artinya kepercayaan berarti lembaga pembiayaan selaku shahibul mal menaruh kepercayaan kepada seseorang untuk melaksanakan amanah yang diberikan.Dana tersebut harus digunakan dengan benar, adil, dan harus disertai dengan ikatan dan syarat-syarat yang jelas, dan saling menguntungkan bagi kedua pihak.

Adapaun defenisi dari pembiayaan secara luas yaitu financing atau pembelanjaan, yaitu pendanaan yang dikeluarkan untuk mendukung investasi yang telah direncanakan, baik yang dilakukan sendiri maupun yang dijalankan orang lain. Dalam arti sempit pembiayaan dipakai untuk mendefenisikan pendanaan yang dilalakukan oleh lembaga pembiayaan, seperti bank syariah kepada nasabah.

Tugas pokok lembaga pembiayaan adalah menghimpun dana dari masyarakat dan menyalurkan kepada masyarakat yang memerlukannya sehingga peranan pembiayaan menjadi sangat penting. Sebagian besar lembaga pembiayaan masih mengandalkan sumber pendapatan utamanya dari operasional pembiayaan sehingga untuk mendapatkan margin yang baik diperlukan pengelolaan

\footnotetext{
${ }^{22}$ Veithzal Rivai dkk, Bank and Financial Institition Management, (Jakarta, PT RajaGrafindo Persada, 2007), hlm 483
} 
18 | Rahmat Ilyas

pembiayaan secara efektif dan efisien.Lembaga keuangan adalah lembaga bisnis yang bergerak dalam pembiayaan dan jasa keuangan lainnya.

\section{DAFTAR PUSTAKA}

Abdul Ghofur Anshori, Perbankan Syariah di Indonesia, Yogyakarta, UGM Press, 2007

Ascarya, Akad dan Produk Bank Syariah , Jakarta:PT.RajaGrafindo Persada, 2011

Lativa M Algaoud \& Mervyn K Lewis, Perbankan Syariah Prinsip Praktik dan Prospek, Jakarta:Serambi Ilmu Semesta, 2003

M. Umer Chapra \& Tariqullah Khan, Regulasi E Pengawasan Bank Syariah, Jakarta: Bumi Aksara, 2008

Muhammad, Manajemen Bank SyariahYogyakarta, AMP YKPN, 2005 Manajemen Pembiayaan Bank Syariah, Yogyakarta:UMP YKPN, 2005 Manajemen Dana Bank Syariah, Yogyakarta, Ekonisia, 2005

Konstruksi Mudharabah dalam Bisnis Syariah; Mudharabah dalam wacana Fiqih dan Praktek ekonomi Modern, Yogyakarta, Pusat Studi Ekonomi Islam STIS, 2003

Muhammad Syafii Antonio, Bank Syariah bagi Bankir \& Praktisi Keuangan,Jakarta, TP, 1999 \&Tazkia Cendekia, 2007

Said Sa'ad Marthon, Ekonomi Islam di Tengah Krisis Ekonomi Global, Jakarta:Zikrul Hakim, tt

Suhartono Zulkifli, Panduan Praktis Transaksi Perbankan Syariah, Jakarta, Zikrul hakim, 2003

Veithzal Rivai \&Andria Permata Veithzal, Islamic Financial Management Jakarta, Rajawali Press, 2008

Veithzal Rivai dkk, Bank and Financial Institition Management, Jakarta, PT RajaGrafindo Persada, 2007

Veithzal Rivai \& H. Arviyan Arifin, Islamic Banking, Jakarta: Bumi Aksara, 2010

Zainul Arifin, Dasar-dasar Manejemen Bank Syariah, Jakarta:Pustaka Alvabet,2006

Zubair Hasan, Bangunan Ekonomi yang berkeadilan, teori, Praktek dan realitas Ekonomi Islam, Yogyakarta, Magistra Insani Perss \& MSI-UII, 2004

Jurnal Hukum dan Ekonomi Syari'ah, Vol. 06 | Nomor 4 